\title{
Extracellular Fluid Space in Rabbit SA Node and Atria as Studied with ${ }^{14} \mathrm{C}$-Inulin and ${ }^{14} \mathrm{C}$-Sucrose*
}

\author{
Onkar Tripathi and Aruni Bhatnagar \\ Pharmacology Division, Central Drug Research Institute, \\ Lucknow-226001, India
}

\begin{abstract}
Summary The extracellular fluid space in rabbit SA node and atrial trabeculae was measured with ${ }^{14} \mathrm{C}$-inulin and ${ }^{14} \mathrm{C}$-sucrose. A larger ${ }^{14} \mathrm{C}$ inulin space in SA node than in the atrial tissue, indicated a greater extracellular fluid space in the former, and could be due to caveolae on the pacemaker cell membrane.
\end{abstract}

Key words: SA node, inulin space.

The pacemaker cells of SA node are reported to be closely packed into a group with fewer gap junctions (James, 1962; Tranum-JEnsen, 1978; Masson-Pevet et al., 1979,1982 ) as compared to the cells of atria and ventricle, indicating the possibility that the extracellular space in the cardiac pacemaker may be quite different from those of the working myocardium. FUKUDA (1984) indeed reported that imulin space in sinus venosus is much larger than in the atrial tissue of frog heart. Although the extracellular space plays an important role in the cellular electrical activity, no information is available on this aspect of the mammalian SA node. An investigation of the extracellular fluid space in rabbit SA node was therefore undertaken presently by determining the ${ }^{14} \mathrm{C}$-inulin space and ${ }^{14} \mathrm{C}$-sucrose space.

Rabbits (1.5-2.0 kg, either sex, CDRI colony) were killed by a blow on the neck, exsanguinated, thoracotomized, and the heart removed. SA node (3-4 mm diam.) was isolated from the rest of the heart by incising around it so as to exclude the crista terminalis, ring bundle, and the opening of superior vena cava. Thin atrial trabeculae $(0.5-0.8 \mathrm{~mm} \times 2-3 \mathrm{~mm})$ were removed from the left atrium. Both the preparations were allowed to heal over and equilibrate in oxygenated HEPES-Tyrode solution (composition in $\mathrm{mm}$ : $\mathrm{NaCl} 137, \mathrm{KCl} 5.4, \mathrm{CaCl}_{2}$ 1.8, HEPES 3, glucose 5, pH 7.4, $36^{\circ} \mathrm{C}$ ) for about $30 \mathrm{~min}$.

For determination of ${ }^{14} \mathrm{C}$-inulin space the spontaneously beating node and

Received for publication August 14, 1987

* CDRI Communication No. 3899. 
atrial preparations, after equilibration, were incubated for $1 \mathrm{~h}$ in oxygenated HEPES-Tyrode solution containing ${ }^{14} \mathrm{C}$-inulin carboxylic acid $(2 \mathrm{mg} / \mathrm{ml}$; specific activity $2-6 \mathrm{mCi} / \mathrm{g}$ ) maintained at $36.5 \pm 0.5^{\circ} \mathrm{C}$. At the end of the incubation period, the tissues were lightly blotted by rolling between two sheets of ashless filter paper, weighed (i.e. wet wt.), and digested in soluene- 100 (accompanied by heating at $50^{\circ} \mathrm{C}$, if necessary). Aliquots of the tissue digests and the loading solution were added to the scintillation cocktail and counted in a liquid scintillation counter. The ${ }^{14} \mathrm{C}$-inulin concentration was determined in the tissue digests as well as in the loading HEPESTyrode solution. The volume of the extracellular fluid space was calculated from the ${ }^{14} \mathrm{C}$-inulin concentration in the tissues and in the loading solution, and expressed as $\mathrm{ml} / \mathrm{g}$ (wet wt.) of the tissue.

For determining the sucrose space, the preparations, after initial equilibration, were incubated in the ${ }^{14} \mathrm{C}$-sucrose-containing $(10 \mu \mathrm{Ci} / \mathrm{ml})$ oxygenated HEPESTyrode solution $\left(36.5 \pm 0.5^{\circ} \mathrm{C}\right)$, to which $1 \mathrm{~mm}$ carrier sucrose had been added. After incubating in this loading solution for $60 \mathrm{~min}$, the tissues were weighed and digested as described above. The tissue digests were added to the scintillation cocktail and counted for radioactivity. The concentrations of ${ }^{14} \mathrm{C}$-sucrose in the tissues and the loading solutions were determined and the sucrose space expressed in $\mathrm{ml} / \mathrm{g}$ (wet wt.) of the tissues.

It is evident from Table 1 that the ${ }^{14} \mathrm{C}$-inulin space in SA node $(0.263 \mathrm{ml} / \mathrm{g})$ is more than twice as much as in the atrial trabeculae $(0.119 \mathrm{ml} / \mathrm{g})$ of rabbit heart, the difference between the values for the two tissues being highly significant.

It can again be seen from Table 1 that unlike the ${ }^{14} \mathrm{C}$-inulin space for the cardiac tissues, the ${ }^{14} \mathrm{C}$-sucrose space was almost equal in the two tissues, being 0.125 and $0.136 \mathrm{ml} / \mathrm{g}$ for $\mathrm{SA}$ node and atrial trabeculae, respectively. The ${ }^{14} \mathrm{C}-$ sucrose space was only slightly larger $(10 \%)$ in the latter than the former, but the difference was not significant.

The above finding that ${ }^{14} \mathrm{C}$-inulin space in SA node was more than twice that of the atrial trabeculae indicated a much larger extracellular space in the mammalian pacemaker tissue as compared to the working myocardium. FUKUDA (1984) reported, likewise, a very large inulin space in frog sinus venosus ( $71 \%$ of wet wt.) as compared to the frog atria ( $45 \%$ of wet wt.). Both these values are, however, larger than those reported for the heart tissue in general (19.1 to $44 \%$ : LEONARD and

Table 1. Values of the extracellular fluid space in terms of ${ }^{14} \mathrm{C}$-inulin and ${ }^{14} \mathrm{C}$-sucrose. in rabbit $\mathrm{SA}$ node and atrial trabeculae.

\begin{tabular}{lllc}
\hline & & \multicolumn{2}{c}{ Extracellular fluid space (in ml/g wet wt.) } \\
\cline { 3 - 4 } S. No. & Tissue & \multicolumn{1}{c}{${ }^{14} \mathrm{C}$-inulin } & ${ }^{14} \mathrm{C}$-sucrose \\
\hline 1. & SA node & $0.263 \pm 0.023(5)$ & $0.125 \pm 0.018(3)$ \\
2. & Atrial trabeculae & $0.119 \pm 0.020(5)$ & $0.136 \pm 0.021(3)$ \\
\hline
\end{tabular}


HAJDU, 1962) and those observed for frog sinus venosus in particular $(28.7 \%$ of wet wt.: Tripathi and Bhatnagar, unpublished observations).

The apparent disagreement in the values of ${ }^{14} \mathrm{C}$-inulin space in the pacemaker and atrial tissues of amphibian heart (FuKUDA, 1984) and those of the mammalian heart (present study) are noteworthy. Very large values obtained for sinus venosus and atria of frog heart could well be due to highly trabeculated and sponge-like structure of these tissues in this species (ECKER and WIEDERSHEIM, 1892), trabeculated structures in heart being known to severely aggravate the problem of determination of extracellular space in the cardiac tissues (LEONARD and HAJDU, 1962). This complicating factor was reduced in the present study by using structurally "simple" tissue preparations, and in the other one (Tripathi and Bhatnagar: unpublished observations) by carefully pressing the frog sinus venosus between sheets of ashless filter paper. The sinus venosus, nevertheless, appears to have a larger extracellular space than the atrial tissue of frog heart as evident from a significantly large difference in the values of ${ }^{14} \mathrm{C}$-inulin space for these two tissues.

The ${ }^{14} \mathrm{C}$-sucrose space, on the other hand, presents a different picture, being about $10 \%$ larger in the atrial trabeculae than in SA node. Although it is difficult to explain at present this difference in the values of ${ }^{14} \mathrm{C}$-inulin and ${ }^{14} \mathrm{C}$-sucrose spaces of the mammalian pacemaker tissue, it may be pointed out that the latter is reported to give erroneous results due to its breakdown by the tissue leading to a loss of radioactivity in the form of ${ }^{14} \mathrm{CO}_{2}$ (MCIVER and MACKNIGHT, 1974).

The present observations, as well as those of FuKUDA (1984), using ${ }^{14} \mathrm{C}$-inulin which is a more reliable marker for extracellular space than ${ }^{14} \mathrm{C}$-sucrose, clearly show that the extracellular fluid space is larger in the pacemaker than in the atrial tissue of rabbit heart. Two factors are likely to account for this difference between the two type of mammalian heart tissue. Firstly, it could be due to rather elaborate vascularization of SA node (JAMES, 1962). The magnitude of difference, however, remains large even after applying a correction factor of 0.03 for residual capillary ${ }^{14} \mathrm{C}$-inulin, as employed for ${ }^{14} \mathrm{C}$-mannitol space in dog heart (CONN and WooD, 1959). The second possibility is offered by the presence of a large number of caveolae on the pacemaker cell membrane. According to the observations of MASSON-PEVET et al. (1982), caveolae contribute more than $100 \%$ to the surface area of the pacemaker cells, which is evidently nil for the atrial cells, increasing the true extracellular space. By applying a correction factor of $100 \%$ to compare the true ${ }^{14} \mathrm{C}$-inulin space of SA node with that of the atrial tissue, the corrected value of ${ }^{14} \mathrm{C}$ inulin space for the pacemaker comes to be very close to the uncorrected one for atrial myocardium, indicating that the interstitial fluid space in the mammalian pacemaker is indeed larger than that of the atria, most probably due to the presence of caveolae on the surface membrane of the former.

Thanks are due to the National Council of Educational Research and Training (NCERT, India), for financial support to A.B. during this study. 


\section{REFERENCES}

ConN, H. L. and Wood, J. C. (1959) Sodium exchange and distribution in the isolated heart of the normal dog. Am. J. Physiol., 197: 631-636.

ECKER, A. and WiedersheIm, R. (1982) Antomie des Frosches, 3rd ed., revised by GaupP, E., Vieweg, Braunschweig.

FuKuDA, Y. (1984) High calcium of pacemaker tissues in frog heart. Jpn. J. Physiol., 34: $1117-1121$.

JAMES, T. N. (1962) Anatomy of the dog sinus node. Anat. Rec., 143: 251-265.

LEONARD, E. and HaJdu, S. (1962) Action of electrolytes and drugs on the contractile mechanism of the cardiac muscle cell. In: Handbook of Physiology, Sec. 2, Circulation, ed. by Hamil ton, W. F. and Dow, P., Williams and Wilkins Co., Baltimore, Vol. I, pp. 151-197.

Masson-Pevet, M., Bleeker, W. K., Beselsen, E., Mackaay, A. J. C., Jongsma, H. J., and Bouman, L. N. (1982) On the ultrastructural identification of pacemaker cell types within the sinus node. In: Cardiac Rate and Rhythm, ed. by Bouman, L. N. and Jongsma, H. J., Martinus Nijhoff Publishers, The Hague, pp. 19-34.

Masson-Pevet, M., Bleeker, W. K., MackaAy, A. J. C., Bouman, L. N., and Houtkoper, J. M. (1979) Sinus node and atrium cell from the rabbit heart: A quantitative electron microscope description after electrophysiological localization. J. Mol. Cell. Cardiol., 11: $555-568$.

MCIver, D. J. L. and MaCknight, A. D. C. (1974) Extracellular space in some isolated tissues. J. Physiol. (Lond.), 239: 31-49.

Tranum-Jensen, J. (1978) The fine structure of the sinus node. In: The Sinus Node. Structure, Function and Clinical Relevance, ed. by BonKe, F. I. M., Martinus Nijhoff Publications, The Hague, pp. 149-165. 